\title{
Results of a Survey of Libraries on Publication Plans for I7th Decennial Census ${ }^{1}$
}

\section{Introduction}

During November and December I948, the chairman of the A.L.A. Committee on Public Documents sent questionnaires to 237 selected libraries requesting recommendations and suggestions which would be useful to the Bureau of the Census in formulating its publication plans for the I950 Census. The 237 libraries which were canvassed included the I24 govern- nous census information, and (b) publication policy for the basic volumes, particularly with respect to such items as title page format, method of serialization, and identification of preliminary and final reports.

The libraries canvassed were selected so as to include, insofar as possible, those which are the most extensive users of Bureau of the Census publications. The group to whom questionnaires were sent was made

Table I

A.L.A. Survey on Publication Preferences for I950 Census Response Status by Type of Library November-December 1948

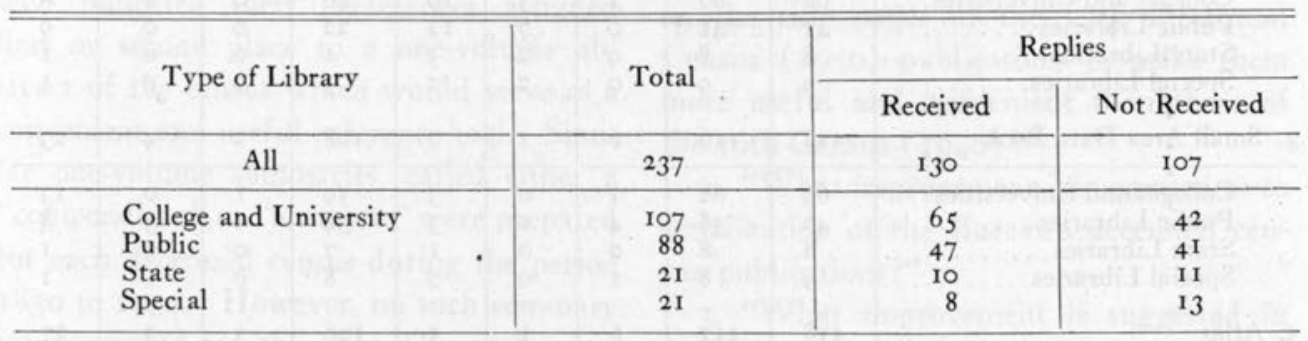

ment "all" depository libraries and other selected lists consisting of 54 public, 39 college and university, and 20 special libraries.

The questionnaire requested the comments, opinions and recommendations of librarians on: (a) general reference works which were proposed as a convenient means of increasing the usefulness of the volumi-

\footnotetext{
1 This report is a summary of results of a survey of libraries on publication plans for 17 th Decennial Census conducted by the Committee on Public Documents, American Library Association, November 1948 , with accompanying recommendations. Jerome $\mathrm{K}$. Wilcox, the chairman of the committee, expresses appreciation to the staff of the Bureau of the Census for their cooperation in furnishing necessary information and assisting in the detailed work.
}

up of 107 large college and state university libraries, 88 public libraries having IOO,000 volumes or more, and a small selected group of special libraries. (See Table I.) These libraries included the 124 federal all-depository libraries.

\section{Summary of Results}

More than one-half ( 55 per cent) of the libraries canvassed replied to the questionnaire ( 73 all-depository, 25 public, 25 college and university, and six special libraries). The replies showed a great deal of interest and a variety of recommendations. 


\section{Proposed 1950 Census Reference Works}

Comments and recommendations regarding one or more proposed reference volumes were made by about $\mathrm{I} 20$ libraries, and an
(See Table II.) This was especially true in the case of the comprehensive index, the one-volume summary of the results of the census, and the small area data book, as

Table II

Summary of Comments ${ }^{1}$ on Proposed Reference Works for 17 th Decennial Census

\begin{tabular}{|c|c|c|c|c|c|c|c|c|c|}
\hline $\begin{array}{l}\text { Type of Publication } \\
\text { and Class of Library }\end{array}$ & $\begin{array}{l}\text { Total } \\
\text { Com- } \\
\text { ments }\end{array}$ & $\begin{array}{c}\text { Defi- } \\
\text { nitely } \\
\text { Favor- } \\
\text { able }\end{array}$ & $\begin{array}{c}\text { Not } \\
\text { Favor- } \\
\text { able }\end{array}$ & $\begin{array}{c}\text { Very } \\
\text { Impor- } \\
\text { tant }\end{array}$ & Impor- & Needed & $\begin{array}{c}\text { Could } \\
\text { be } \\
\text { Omit- } \\
\text { ted }\end{array}$ & $\begin{array}{c}\text { Not } \\
\text { Needed }\end{array}$ & $\begin{array}{l}\text { No } \\
\text { Com- } \\
\text { ment }\end{array}$ \\
\hline I. History & II & 100 & 19 & 2 & 2 & 96 & 13 & 6 & 26 \\
\hline $\begin{array}{l}\text { Colleges and Universities.... } \\
\text { Public Libraries........... } \\
\text { State Libraries ........... } \\
\text { Special Libraries......... }\end{array}$ & $\begin{array}{r}62 \\
41 \\
8 \\
8\end{array}$ & $\begin{array}{r}55 \\
33 \\
7 \\
5\end{array}$ & $\begin{array}{l}7 \\
8 \\
1 \\
3\end{array}$ & $\begin{array}{l}\mathbf{I} \\
\mathbf{1} \\
0 \\
0\end{array}$ & $\begin{array}{l}2 \\
0 \\
0 \\
0\end{array}$ & $\begin{array}{r}52 \\
32 \\
7 \\
5\end{array}$ & $\begin{array}{l}5 \\
6 \\
1 \\
1\end{array}$ & $\begin{array}{l}2 \\
2 \\
0 \\
2\end{array}$ & $\begin{array}{r}\mathrm{I} 4 \\
9 \\
1 \\
2 \\
2\end{array}$ \\
\hline 2. Abstract & 123 & 113 & 10 & 3 & I6 & 94 & 6 & 4 & 22 \\
\hline $\begin{array}{l}\text { Colleges and Universities.... } \\
\text { Public Libraries........... } \\
\text { State Libraries ........... } \\
\text { Special Libraries }\end{array}$ & $\begin{array}{r}67 \\
39 \\
8 \\
9\end{array}$ & $\begin{array}{r}62 \\
35 \\
8 \\
8\end{array}$ & $\begin{array}{l}5 \\
4 \\
0 \\
1\end{array}$ & $\begin{array}{l}1 \\
2 \\
0 \\
0\end{array}$ & $\begin{array}{r}10 \\
5 \\
1 \\
0\end{array}$ & $\begin{array}{r}51 \\
28 \\
7 \\
8\end{array}$ & $\begin{array}{l}3 \\
3 \\
0 \\
0\end{array}$ & $\begin{array}{l}2 \\
1 \\
0 \\
1\end{array}$ & $\begin{array}{r}9 \\
\text { II } \\
\text { I } \\
\text { I }\end{array}$ \\
\hline 3. Index & 126 & 125 & I & 16 & 35 & 74 & $\circ$ & I & 19 \\
\hline $\begin{array}{l}\text { Colleges and Universities.... } \\
\text { Public Libraries........... } \\
\text { State Libraries............ } \\
\text { Special Libraries........ }\end{array}$ & $\begin{array}{r}68 \\
4 \mathrm{I} \\
8 \\
9\end{array}$ & $\begin{array}{r}67 \\
4 \mathrm{I} \\
8 \\
9\end{array}$ & $\begin{array}{l}\mathbf{I} \\
0 \\
0 \\
0\end{array}$ & $\begin{array}{l}5 \\
7 \\
2 \\
2\end{array}$ & $\begin{array}{r}16 \\
12 \\
5 \\
2\end{array}$ & $\begin{array}{r}46 \\
22 \\
1 \\
5\end{array}$ & $\begin{array}{l}0 \\
0 \\
0 \\
0\end{array}$ & $\begin{array}{l}\text { I } \\
0 \\
0 \\
0\end{array}$ & $\begin{array}{l}8 \\
9 \\
1 \\
1\end{array}$ \\
\hline 4. Small Area Data Book & 122 & 116 & 6 & I & 7 & 108 & 2 & 4 & 23 \\
\hline $\begin{array}{l}\text { Colleges and Universities.... } \\
\text { Public Libraries.......... } \\
\text { State Libraries............ } \\
\text { Special Libraries......... }\end{array}$ & $\begin{array}{r}63 \\
42 \\
8 \\
9\end{array}$ & $\begin{array}{r}62 \\
38 \\
8 \\
8\end{array}$ & $\begin{array}{l}\text { I } \\
4 \\
0 \\
\text { I }\end{array}$ & $\begin{array}{l}\circ \\
1 \\
\circ \\
\circ\end{array}$ & $\begin{array}{r}3 \\
3 \\
. \quad 1 \\
0\end{array}$ & $\begin{array}{r}59 \\
34 \\
7 \\
8\end{array}$ & $\begin{array}{l}1 \\
1 \\
0 \\
0\end{array}$ & $\begin{array}{l}0 \\
3 \\
0 \\
1\end{array}$ & $\begin{array}{r}13 \\
8 \\
1 \\
1\end{array}$ \\
\hline 5. Atlas & 118 & 112 & 6 & I & 5 & 106 & 3 & 3 & 27 \\
\hline $\begin{array}{l}\text { Colleges and Universities..... } \\
\text { Public Libraries............ } \\
\text { State Libraries............ } \\
\text { Special Libraries......... }\end{array}$ & $\begin{array}{r}59 \\
42 \\
8 \\
9\end{array}$ & $\begin{array}{r}55 \\
40 \\
8 \\
9\end{array}$ & $\begin{array}{l}4 \\
2 \\
0 \\
0\end{array}$ & $\begin{array}{l}0 \\
1 \\
0 \\
0\end{array}$ & $\begin{array}{l}5 \\
0 \\
0 \\
0\end{array}$ & $\begin{array}{r}50 \\
39 \\
8 \\
9\end{array}$ & $\begin{array}{l}2 \\
1 \\
0 \\
0\end{array}$ & $\begin{array}{l}2 \\
1 \\
0 \\
0\end{array}$ & $\begin{array}{r}17 \\
8 \\
1 \\
1\end{array}$ \\
\hline
\end{tabular}

1 Includes 15 comments received as a result of announcements of proposed reference works in the December 1948 Wilson Library Bulletin and Dec. I, I 948 Library Journal.

additional 15 libraries made suggestions as a result of the announcements regarding the proposed general reference works in the December 1948 Wilson Library Bulletin and the Dec. I, 1948, Library Journal.

Practically all libraries which replied expressed a high degree of interest in the five proposed reference volumes mentioned and pointed out the need for these library tools. indicated by the librarians who stated their order of preference.

Librarians were unanimous in assigning highest priority to a comprehensive index to all publications of the 1950 Census. The comments expressed a strong need for a comprehensive detailed index which would analyze the tabular contents of all the 1950 Census volumes rather than merely list the 
general subject contents of each volume. Such an index should have the same degree of detail as a smaller subject index, for each volume but would consist of a single volume covering the entire census. Many librarians pointed out that the large number of census reports and the wide variety of subjects covered make it very difficult to use intelligently the census volumes without an adequate analytical index, and that a detailed index of this kind would immeasurably increase the accessibility and usefulness of the census information. Perhaps a special edition of the Census Bureau's Catalog and Subject Guide could be prepared.

Expressions of opinion from librarians who indicated the order of preference among the reference works ranked the proposed one-volume summary of the results of the census second in order of importance. Approximately four-fifths of the librarians who indicated their preferences assigned first or second place to a one-volume abstract of the census which would serve as a convenient and useful reference tool. Similar one-volume summaries, called either a "compendium" or "abstract," were prepared for each decennial census during the period I 850 to 1930 . However, no such summary was prepared for the 1940 Census because of limitations imposed by the War.

Almost all (95 per cent) of the respondents also agreed that a small area data book summarizing the most important data collected for cities and counties in a single volume would constitute an important reference tool. Many reference librarians pointed out that an increasing proportion of requests are for information on specific local areas. A similar compilation, called the County Data Book, was published by the Bureau of the Census in 1947.

Other general publications proposed included a statistical atlas, a history of the census, a guide to the use of the census, state compendiums, and similar publications. While the need for these publications is not as great as is that for the three recommended above, it is strongly urged that these additional publications be prepared, as funds permit.

The three publications recommended above, the comprehensive index, the summary volume, and the small area data book, however, are essential library tools and should be included as basic publications of the 17 th Decennial Census.

\section{Publication Style}

The following inquiries on preferred publication style for the 1950 Census were submitted to librarians with statements on the previous experience of the Bureau of the Census:

I. "What information should be included on the title pages of the 17 th Decennial Census (1950) publications to make them more useful and convenient than those of the I6th Census (1940) ?"

2. "What improvement is suggested as to serialization of the Bureau's decennial census publications?"

3. "What improvement is suggested in the indication as to the preliminary or final nature of the data in the various publications?"

The Bureau's statement outlining the essential features of the 1940 Census in regard to the above problems noted that previous publication practices had apparently not fully met the needs of catalogers and reference librarians. The statements mentioned possible alternatives for improving publication style, but called attention to the fact that certain practical requirements in the preparation of census volumes made a simple solution of these problems very difficult. 


\section{Title Page Format}

Replies to the query on title page format were received from 129 libraries. (See Table III.) The purpose of this query was to determine whether librarians preferred a rather detailed title page, as in the I940 Census, or a much simplified title page. The preferences expressed by librarians on the choice of detailed versus of the title on each title page (e.g., United States Seventeenth Decennial Census: 1950 Population Volume I, Part I). This would then be followed by the volume and part titles and other necessary information. It will be necessary, of course, to so plan the page that it will be clear to the user as to which is the volume and which is the part title.

\begin{tabular}{|c|c|c|}
\hline \multirow[b]{2}{*}{ Type of Title Page Preferred } & \multicolumn{2}{|c|}{ Replies } \\
\hline & Number & $\begin{array}{c}\text { Percent of } \\
\text { Total }\end{array}$ \\
\hline All ............... & 129 & 100 \\
\hline 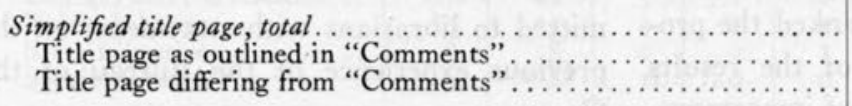 & $\begin{array}{l}61 \\
37 \\
24\end{array}$ & $\begin{array}{l}47 \\
29 \\
18\end{array}$ \\
\hline 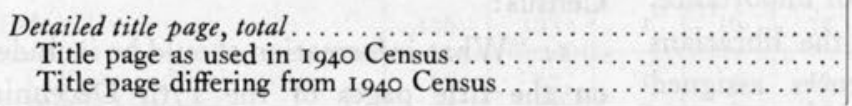 & $\begin{array}{l}68 \\
57 \\
\text { II }\end{array}$ & $\begin{array}{r}53 \\
44 \\
9\end{array}$ \\
\hline
\end{tabular}

simplified title page were almost evenly divided. However the comments and suggestions regarding this question varied considerably with respect to the exact amount and kind of information which should be included on the title page. The nature of the comments indicated that reference librarians apparently prefer detailed title pages, while those concerned with acquisitions and cataloging leaned toward limiting the information on the title page to the minimum required for identification and convenience in shelving.

In view of these returns, it appears that a title page format having the following characteristics might fulfil the requirements of most librarians. The title page should show detail similar to that shown on the I940 Population Census title pages but would group the series name, subject group, and volume and part notation at the head

\section{Serialization of Census Reports}

Approximately 120 librarians made suggestions and recommendations on the serialization of the decennial census reports. These recommendations almost unanimously favored more complete serialization of the census reports, but differed considerably with respect to preferred methods of organization. As shown in Table IV, slightly more than one-third ( 36 per cent) of the librarians recommended some form of complete serialization; almost the same proportion (3I per cent) favored partial serialization, while a fourth of the respondents preferred serialization of all reports or as many reports as possible. Some of the respondents favoring complete serialization recommended the numbering of all census reports in one consecutive series, while others suggested that all reports on a given subject be numbered in the same series. 


\begin{tabular}{|c|c|c|}
\hline \multirow[b]{2}{*}{ Method of Serialization Preferred } & \multicolumn{2}{|c|}{ Replies } \\
\hline & Number & $\begin{array}{c}\text { Percent of } \\
\text { Total }\end{array}$ \\
\hline All ............................... & II 9 & 100 \\
\hline 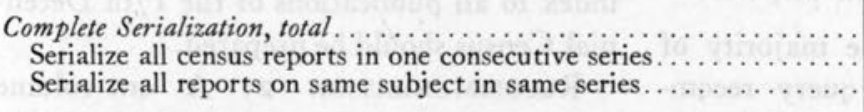 & $\begin{array}{l}43 \\
26 \\
17\end{array}$ & $\begin{array}{l}36 \\
22 \\
14\end{array}$ \\
\hline 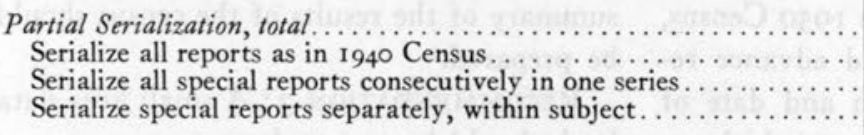 & $\begin{array}{r}37 \\
11 \\
8 \\
18\end{array}$ & $\begin{array}{r}31 \\
9 \\
7 \\
15\end{array}$ \\
\hline Serialize All or as many Reports as Possible, total................. & 28 & 24 \\
\hline 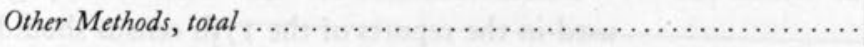 & II & 9 \\
\hline
\end{tabular}

Preferences of librarians recommending partial serialization suggest three general methods. One group recommended that all special reports be serialized separately from the basic reports by numbering all special reports, irrespective of subject, in one consecutive series. Another group preferred the serialization of special reports within broad subject groups. The third group suggested the same method of serialization used for the 1940 Census reports.

Considering the divergent viewpoints of librarians and the practical difficulties of consecutively numbering all reports of the 1950 Census, it appears that numbering or serializing all 1950 Census reports within broad major subject groups would best meet the needs of most librarians. Classification

Table V

Summary of Recommendations for Improving Identification of Preliminary or Final Nature of 1950 Census Data and Reports

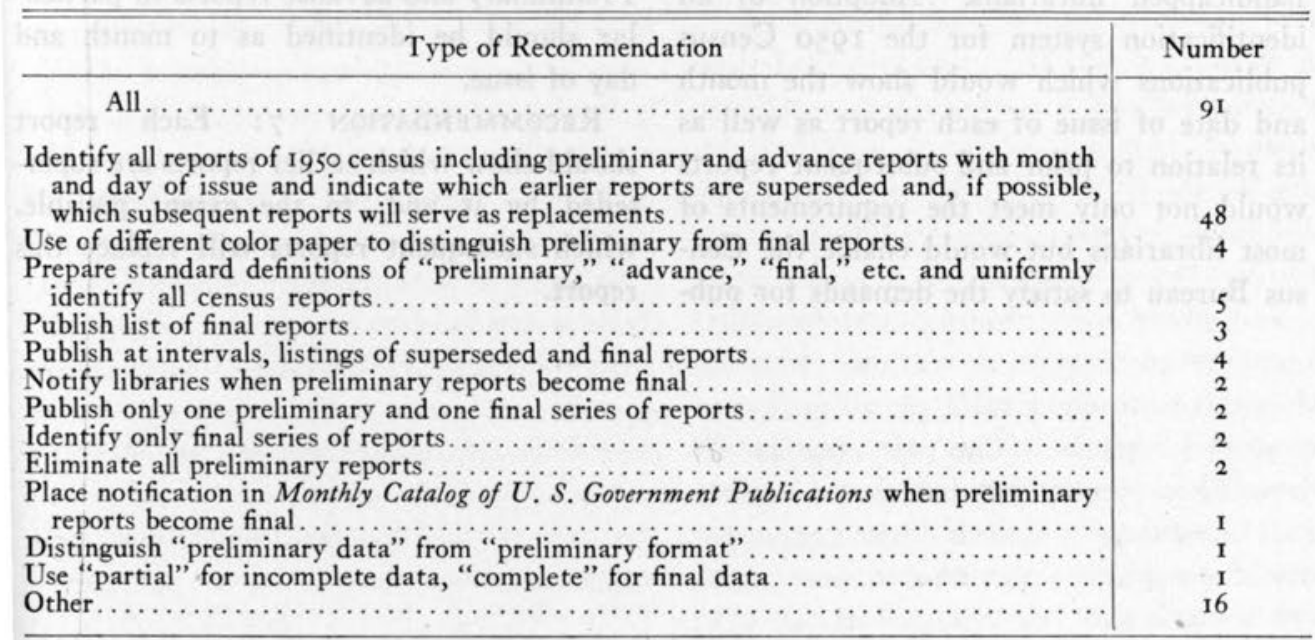


of reports by major subject group would increase their usefulness for reference purposes, while the numbering of both basic and special reports would facilitate their cataloging.

Identification of Preliminary or Final Nature of 1950 Census Data and Reports

As shown in Table $\mathrm{V}$, the majority of the $9 \mathrm{I}$ respondents to this query recommended that all reports of the I950 Census, especially the preliminary and advance reports, be identified by month and date of issue and that each report show which report or reports it supersedes or which subsequent reports will replace it.

Numerous other suggestions for distinguishing between preliminary and final reports were also received. Some comments suggested the use of a different color paper for preliminary and final reports. Others recommended the publication of a list of final reports; publication at intervals of lists of superseded and final reports; or informing libraries when preliminary reports become final, etc.

It is apparent from the nature and variety of replies to this query that the lack of clearcut identification of the preliminary or final nature of previous census publications has handicapped librarians. Adoption of an identification system for the I950 Census publications which would show the month and date of issue of each report as well as its relation to prior and subsequent reports would not only meet the requirements of most librarians but would enable the Census Bureau to satisfy the demands for pub- lication of data at the earliest possible moment.

Recommendations on Proposed Reference Works and Publication Policy for the I7th Decennial Census

Recommendation I: A comprehensive index to all publications of the 17 th Decennial Census should be prepared.

Recommendation 2: A one-volume summary of the results of the census should be prepared.

Recommendation 3: A small area data book should be prepared.

Recommendation 4: The title page used in the reports of the $\mathrm{I} 7$ th census should be standardized and show detail similar to that of r940 Population Census title pages. However, at the head of the title on each title page should appear the serialized subject title with volume and part notation (e.g. United States Seventeenth Decennial Census: I950 Population Volume I, Part I).

Recommendation 5: All reports of the I 7 th Decennial Census should be numbered or serialized within broad subject groups, such as population, agriculture, etc.

Recommendation 6: All reports of the I 7 th census should show the date of issue. Preliminary and advance reports in particular should be identified as to month and day of issue.

RECOMMENDATION 7: Each report should show which earlier reports are superseded by it and, to the extent possible, which subsequent reports will replace this report. 